\title{
The development of combustion engines for hybrid drive systems
}

\begin{abstract}
Continuous increased interest in hybrid drive systems enabling the reduction of fuel consumption and emissions of harmful substances into the atmosphere, as well as their use partly as zero-emission drive in vehicles provides the basis for the development of these types of drive systems. Such trend is indicated by sales analysis of hybrid drives, and this means that actions taken towards of reduction of fuel consumption are still justified. The article reviews combustion engines for hybrid drive systems as far as determination of their operating conditions, indicating mean effective pressure and power/displacement ratio are considered. The concept of hybridization was defined as a measure of the degree of utilization of vehicle electric drive systems (or its drive support). The analysis was conducted on the basis of vehicles equipped with different hybrid drive systems with combustion engines with spark ignition and compression ignition. The hybridization indexes for different groups of hybrid drive systems were determined and significant discrepancies in the way of their determination were pointed out.
\end{abstract}

Key words: hybrid drive systems, hybridization of vehicles, combustion engine, electric motor

\section{Rozwój silników spalinowych napędów hybrydowych}

Ciagty wzrost zainteresowania napędami hybrydowymi pozwalajacymi na ograniczenie zużycia paliwa, zmniejszenie emisji składników szkodliwych do atmosfery, a także częściowe ich wykorzystanie jako pojazdów zeroemisyjnych powoduje rozwój tych jednostek. Wskazuja na to analizy sprzedaży napędów hybrydowych, a to oznacza aktualność działań podejmowanych w kierunku ograniczenia zużycia paliwa. W artykule dokonano przegladu silników spalinowych napędów hybrydowych w aspekcie określenia ich warunków pracy oraz wskaźników wysilenia. Określono pojęcie hybrydyzacji jako miary stopnia wykorzystania układów elektrycznych napędu pojazdu (lub jego wspomagania). Analizy dokonano $w$ odniesieniu do pojazdów wyposażonych $w$ różne systemy napędu hybrydowego z silnikami spalinowymi o zapłonie iskrowym i samoczynnym. Określono wskaźniki hybrydyzacji różnych grup napędów hybrydowych oraz wskazano na znaczne rozbieżności w sposobie ich określania.

Słowa kluczowe: napędy hybrydowe, hybrydyzacja pojazdów, silnik spalinowy, silnik elektryczny

\section{Introduction}

Search for the possibilities of reducing fuel consumption and emissions of harmful components of exhaust gases are the reason why the vehicle drive systems undergo continuous development. This applies to the combustion engine itself as well as to the complete drive systems. The studies now undertaken, contributing to the development of combustion engines, mainly include:

- fuel combustion systems: the dominance of direct fuelinjection in both compression-ignition and spark ignition engines,

- inlet and outlet system using variable engine timing in order to obtain increased filling of cylinders and a variable degree of exhaust gas recirculation,

- the use of low-and high pressure exhaust gas recirculation system to reduce emissions of harmful substances,

- materials limiting friction losses within piston-crank systems,

- the possibility of increasing the thermal efficiency of an engine by the appropriate management of the cooling systems,

- the use of exhaust gas purification systems focused primarily on reducing emissions of particle mass and particle number.

\section{Wstęp}

Poszukiwanie możliwości ograniczania zużycia paliwa oraz zmniejszenia emisji składników szkodliwych spalin powodują, że napędy pojazdów ulegają ciągłemu rozwojowi. Rozwój ten dotyczy zarówno samych silników spalinowych, jak również całych układów napędowych. Podejmowane obecnie działania przyczyniające się do rozwoju silników spalinowych dotyczą głównie:

- systemów spalania paliwa - dominacja układów bezpośredniego wtrysku paliwa zarówno w silnikach o zapłonie samoczynnym, jak i iskrowym,

- układów dolotowych i wylotowych wykorzystujących zmienne fazy rozrządu w celu uzyskania zwiększonego napełnienia cylindrów oraz zmiennego stopnia recyrkulacji spalin,

- stosowania nisko- i wysokociśnieniowego systemu recyrkulacji spalin w celu ograniczenia emisji składników szkodliwych [5],

- materiałów ograniczających straty tarcia w układach tłokowo-korbowych,

- możliwości zwiększenia sprawności cieplnej silnika przez odpowiednie zarządzanie układami chłodzenia,

- stosowania systemów oczyszczania spalin ukierunkowanych głównie na obniżanie emisji liczbowej i masowej cząstek stałych. 
Most of the presented actions are elements of the combustion engines downsizing process defined as static (concerning the reduction of engine displacement) or dynamic (involving deactivation of some of the cylinders during engine operation) [3].

Development of vehicle drive systems focuses first of all on reducing emissions of carbon dioxide, which means that any actions leading to reduction on the use of a combustion engine are desirable, especially in the view of planned reduction of $\mathrm{CO}_{2}$ emission to the level of $95 \mathrm{~g} / \mathrm{km}$ by 2020 . This means that the increase in the share of operation of electric drive systems in motor vehicles contributes to the development of both combustion engines and electric motors.

The aim of this paper is to define the conditions of operation of combustion engines and electric motors and the analysis of changes in indexes of operation of combustion engines and electric motors in hybrid drive systems. Such analysis was conducted taking into account the type of hybrid drive system of the vehicle. The obtained indexes of engine operation were used to determine the degree of hybridization of the presented drive systems.

\section{Division of hybrid drive systems}

A hybrid drive system involves co-operation of the primary and secondary drive systems in a vehicle. What it means is that in a hybrid vehicle should be two (in some cases independent) drive systems. Currently it is assumed that in most cases combustion engine is the primary drive system, while most commonly the secondary source is a battery with electric motor (in case of the Range Extender drive systems, the role of the primary drive system might be taken over by the battery and electric motor).

The development of alternative designs of vehicle drive systems made it necessary to systematize them. The hybrid drive systems currently introduced into the market might be divided according to different division criteria. Considering as the first division criteria the share of electric drive system in a vehicle, the vehicles can be divided into [9]:

1) micro hybrid - this term refers to vehicles that use only the stop-start systems (stopping and starting the combustion engine under certain traffic conditions),

2) mild hybrid (mild hybrid drive system) - contains the system of electrical machine (electric motor), whose task is to support the operation of the combustion engine and energy recuperation during braking (this solution includes additionally the stop-start system),

3) full hybrid (full hybrid drive system) - is a hybrid system, in which the combustion engine and the electric motor (also used as a power generator) cooperate; it is possible to drive the vehicle with one of the drive systems at a time (in addition, this solution contains systems of the two above-mentioned solutions).

The design criterion introduces the division of the hybrid drive systems into three groups [9]:

a) serial drive system - wheels driven by an electric motor,

b) parallel drive system - wheels driven by a combustion engine and/or by electric motor,
Większość z przedstawionych działań jest elementem downsizingu silników spalinowych określanego jako statyczny (dotyczący zmniejszenia pojemności skokowej silnika) lub dynamiczny (polegający na deaktywacji części cylindrów podczas pracy silnika) [3].

Rozwój napędów pojazdów ukierunkowany jest przede wszystkim na ograniczenie emisji dwutlenku węgla, co powoduje, że wszelkie prace prowadzące do ograniczenia wykorzystania silnika spalinowego są pożądane, szczególnie $w$ aspekcie zapowiadanego ograniczenia emisji $\mathrm{CO}_{2}$ do poziomu $95 \mathrm{~g} / \mathrm{km}$ w roku 2020. Oznacza to, że zwiększenie udziału napędów elektrycznych w pojazdach samochodowych jest kierunkiem powodującym rozwój zarówno silników spalinowych, jak i elektrycznych.

Celem pracy jest określenie warunków pracy silników spalinowych i elektrycznych oraz analiza zmian wskaźników pracy tych silników stosowanych w napędach hybrydowych. Analizy takiej dokonano z uwzględnieniem rodzaju napędu hybrydowego pojazdu. Uzyskane wskaźniki pracy silników spalinowych posłużyły do wyznaczenia stopnia hybrydyzacji prezentowanych napędów.

\section{Podział napędów hybrydowych}

Układ hybrydowy to współdziałanie pierwotnego i wtórnego źródła napędu w pojeździe. Wynika z tego, że w pojeździe o napędzie hybrydowym powinny znajdować się dwa (czasami niezależne) źródła napędu. Obecnie przyjmuje się, że w większości źródło pierwotne stanowi silnik spalinowy, natomiast źródło wtórne - najczęściej akumulator z silnikiem elektrycznym (w odniesieniu do napędów typu Range Extender możliwe jest przejęcie roli źródła pierwotnego przez układ akumulatora i silnika elektrycznego).

Rozwój alternatywnych konstrukcji napędów pojazdów stwarza konieczność ich systematyki. Z tego powodu obecnie wprowadzane na rynek napędy hybrydowe można podzielić ze względu na różne kryteria tego podziału. Przyjmując za pierwsze z nich udział napędów elektrycznych w pojeździe, możliwe jest uwzględnienie podziału na [9]:

1) micro hybrid - termin ten odnosi się do pojazdów, w których zastosowano jedynie układy start-stop (zatrzymania i uruchamiania silnika spalinowego w określonych warunkach ruchu),

2) mild hybrid (łagodny napęd hybrydowy) - zawiera układ maszyny elektrycznej (silnik elektryczny), której zadaniem jest wspomaganie pracy silnika spalinowego oraz odzyskiwanie energii podczas hamowania pojazdem (dodatkowo rozwiązanie to zawiera system start-stop),

3) full hybrid (pełny napęd hybrydowy) - układ hybrydowy, w którym współdziałają ze sobą silnik spalinowy i elektryczny (wykorzystywany również jako generator prądu); możliwy jest jednocześnie napęd jednym z tych silników (dodatkowo rozwiązanie to zawiera systemy dwóch poprzednich rozwiązań napędów).

Kryterium konstrukcyjne pozwala na podział napędów hybrydowych na trzy grupy [9]:

a) napęd szeregowy - napęd na koła przenoszony jest przez silnik elektryczny, 
c) serial-parallel drive system - utilizing advantages of serial and parallel drive systems to transfer power and torque to the wheels of the vehicle.

The now dominant parallel drive system (mild hybrid and full hybrid) may soon be completely replaced by vehicles using the serial drive system. Due to the significant development of the lithium-ion batteries, introduction of vehicles with such drive into the market is more and more common. Such manufacturers as, among others, Chevrolet or BMW have already introduced such vehicles into the market; they are referred to as extended-range vehicles (Range Extender) [10]. The target seems to be the market of electric vehicles: small vehicles the representatives of which are e.g. BMW i3, Citreon C-Zero, Peugeot iOn, Mitsubishi i-MiEV, as well as market of middle and upper class vehicles (e.g. Nissan Leaf, Tesla Model S) [4, 13].

\section{Combustion engines for hybrid drive systems}

\subsection{Introduction}

Here are presented the characteristics of combustion engines operation and the analysis of the operating indexes for selected representatives of particular groups of hybrid drive systems. The analysis was carried out for vehicles of full hybrid and mild hybrid systems as well as for serial drive systems. The representatives of the different groups of hybrid drive systems are shown in Figure 1. Analysing the figure it might be observed that the vehicles of full hybrid type in majority have the power of combustion engines not much higher than the power of electric motors.

The latest full hybrid solutions indicate also the possibility of limiting the power of the electric motor (Peugeot 3008 HYbrid4). In case of Peugeot drive this results from the independent drive of the two axles by the combustion engine and electric motor. The combustion engine drives the front axle of b) napęd równoległy - napęd na koła przenoszony jest przez silnik spalinowy lub/oraz przez silnik elektryczny,

c) napęd szeregowo-równoległy - wykorzystanie zalet napędu szeregowego oraz równoległego przy przeniesieniu mocy i momentu obrotowego na koła pojazdu.

Dominujący obecnie napęd równoległy (mild hybrid oraz full hybrid) może wkrótce być częściowo zastąpiony pojazdami wykorzystującymi napęd szeregowy. Ze względu na znaczny rozwój akumulatorów litowo-jonowych wprowadzanie takich pojazdów na rynek jest coraz powszechniejsze. Tacy producenci, jak m.in. Chevrolet, BMW już wprowadzili takie pojazdy na rynek; są one określane pojazdami o zwiększonym zasięgu (Range Extender) [10]. Docelowy wydaje się rynek pojazdów elektrycznych, na którym można wskazać przedstawicieli małej (m.in. BMW i3, Citreon C-Zero, Peugeot iOn, Mitsubishi i-MiEV) oraz średniej i wyższej klasy pojazdów (m.in. Nissan Leaf, Tesla Model S) [4, 13].

\section{Silniki spalinowe napędów hybrydowych}

\subsection{Wprowadzenie}

Charakterystyki pracy silników spalinowych oraz analizę wskaźników operacyjnych przedstawiono dla wybranych reprezentantów poszczególnych grup napędów hybrydowych. Analizy prowadzono dla pojazdów typu full hybrid, mild hybrid oraz układów szeregowych. Przedstawicieli różnych grup napędów hybrydowych przedstawiono na rysunku 1. Z jego analizy wynika, że pojazdy typu full hybrid w większości mają silniki spalinowe o mocach niewiele większych od mocy silników elektrycznych.

Najnowsze rozwiązania napędów pełnohybrydowych (full hybrid) wskazują również na możliwość ograniczenia mocy silnika elektrycznego (Peugeot 3008 HYbrid4). Dla napędu Peugeota wynika to $\mathrm{z}$ niezależnego napędu dwóch osi przez oba silniki. Silnik spalinowy napędza oś przednią

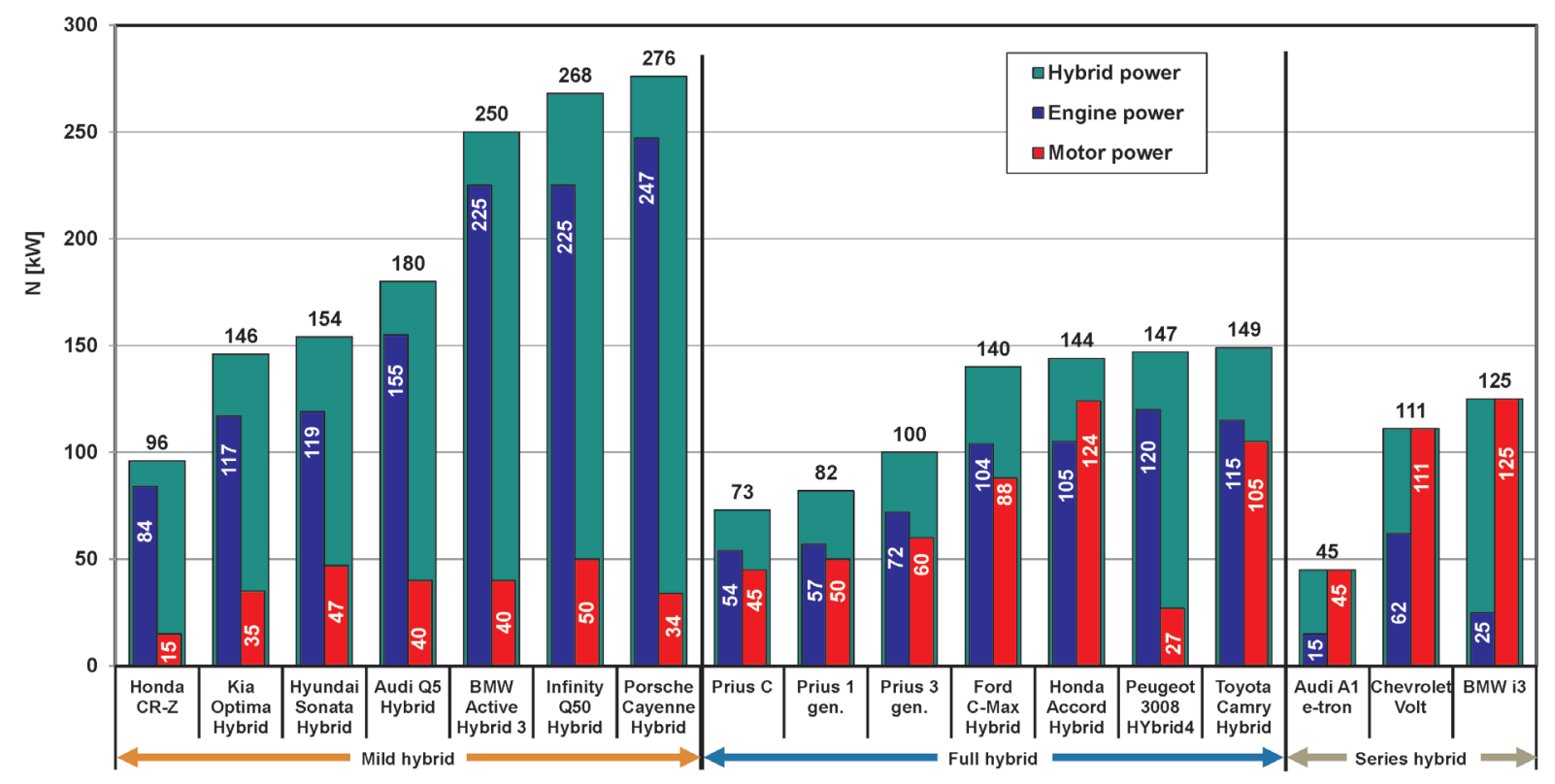

Fig. 1. The analysis of the power of hybrid systems, taking into account the division of hybrid drive systems [1, 7, 8, 12, 15-19] Rys. 1. Analiza mocy systemów hybrydowych z uwzględnieniem podziatu napędów hybrydowych [1, 7, 8, 12, 15-19] 
the vehicle, and the electric motor - only the rear axle.

The design solution of Hyundai and Kia (parallel drive system - mild hybrid) with electric motors of appropriately large power enable the operation of these drives in electric mode. In case of Hyundai, the maximum speed of the vehicle in this mode amounts to $120 \mathrm{~km} / \mathrm{h}$ [18].

\subsection{The analysis of operation of combustion engines found in the full hybrid systems}

In order to obtain high efficiency of combustion engine, quite often the Atkinson cycle is used. It is characterized by a delayed closing of the intake valve, reducing pumping losses, and this promotes the increase of thermal efficiency while limiting the power of the engine. Compensation of compression losses is achieved by increasing the compression ratio of these engines. Today, many manufacturers of combustion engines use this type of solution in hybrid drive systems.

The following are the analyses of operation of Toyota and Lexus combustion engines, being currently the representatives of the most often sold hybrid vehicles. They utilize the full hybrid drive system (serial-parallel), enabling power distribution - the so-called power-split.

The characteristics of engine torque for 2ZR-FXE engine (III generation Toyota Prius, combustion engine displacement of $1.8 \mathrm{dm}^{3}$ ) is much more beneficial than in case of hybrid drive of the previous generation with the 1NZ-FXE engine (I generation Toyota Prius), due to achieving higher values of the maximum torque of about $30 \mathrm{~N} \cdot \mathrm{m}$ (Fig. 2a). However, taking into account the increase of the engine displacement (from $1.5 \mathrm{dm}^{3}$ up to $1.8 \mathrm{dm}^{3}$ ), the power/displacement ratio for the new designs is not significantly larger (Fig. 2b). The analysis of the combustion engine operation characteristics (and not the external characteristics) in operation conditions of hybrid drive systems indicates that the earlier version of the 1NZ-FXE engine operated within the range of higher effective pressures than the currently utilised pojazdu, silnik elektryczny - tylko oś tylną.

Rozwiązania konstrukcyjne firm Hyundai i Kia (napęd równoległy - mild hybrid) z silnikami elektrycznymi o odpowiednio dużych mocach pozwalają na pracę tych napędów w trybie elektrycznym. W odniesieniu do Hyundaia maksymalna prędkość pojazdu w tym trybie wynosi $120 \mathrm{~km} / \mathrm{h}$ [18].

\subsection{Analiza pracy silników spalinowych występujących w ukladach full hybrid}

W celu uzyskania dużej sprawności silnika spalinowego często wykorzystywany jest obieg Atkinsona. Cechuje się on późnym zamknięciem zaworu dolotowego, co umożliwia ograniczenie strat pompowania, a to sprzyja zwiększeniu sprawności cieplnej przy jednoczesnym ograniczeniu mocy takiego silnika. Rekompensowanie strat sprężania uzyskuje się przez zwiększenie stopnia sprężania tych silników. Obecnie wielu producentów silników spalinowych wykorzystuje tego typu rozwiązania w napędach hybrydowych pojazdów.

Poniżej przedstawiono analizy pracy silników spalinowych firmy Toyota oraz Lexus będących przedstawicielami najczęściej obecnie sprzedawanych pojazdów hybrydowych. Wykorzystują one napęd pełnohybrydowy (szeregowo-równoległy), pozwalający na rozdział mocy tzw. power-split.

Przebieg momentu obrotowego silnika 2ZR-FXE (Toyota Prius III generacji, silnik spalinowy o pojemności skokowej 1,8 $\mathrm{dm}^{3}$ ) jest znacznie korzystniejszy niż napędu hybrydowego poprzedniej generacji z silnikiem 1NZ-FXE (Toyota Prius I generacji), gdyż uzyskuje większe wartości momentu maksymalnego o około $30 \mathrm{~N} \cdot \mathrm{m}$ (rys. 2a). Jednak biorąc pod uwagę zwiększenie pojemności skokowej silnika (z 1,5 dm ${ }^{3}$ do $1,8 \mathrm{dm}^{3}$ ), wysilenie nowej konstrukcji nie jest znacząco większe (rys. 2b). Analiza linii pracy silnika spalinowego (a nie charakterystyka zewnętrzna) w warunkach pracy napędu hybrydowego wskazuje, że we wcześniejszej wersji silnik 1NZ-FXE pracował w zakresie większych ciśnień użytecznych niż w wersji obecnej-2ZR-FXE [14]. Różnica

b)

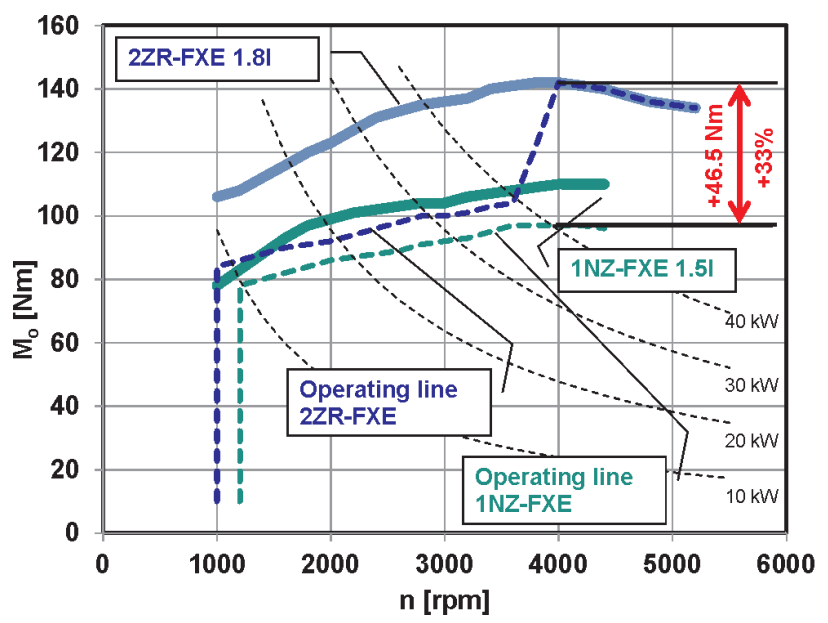

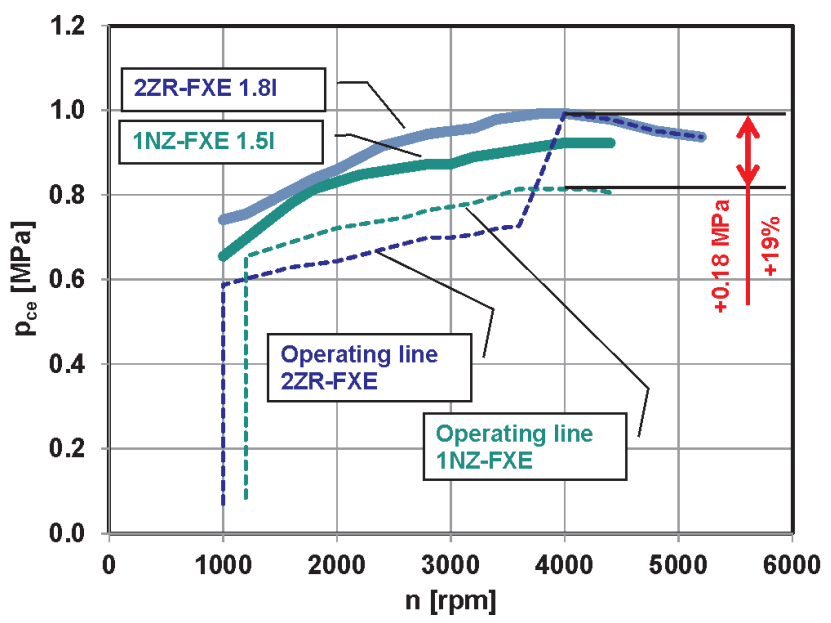

Fig. 2. Comparison of the characteristics of the combustion engines of successive generations of Toyota Prius hybrid drive systems: a) torque, b) mean effective pressure with operation conditions of these engines in hybrid systems

Rys. 2. Porównanie charakterystyk silników spalinowych kolejnych generacji napędów hybrydowych Toyoty Prius: a) momentu obrotowego, b) średniego ciśnienia użytecznego wraz z naniesionymi warunkami pracy tych silników w układach hybrydowych 
2ZR-FXE version [14]. This difference is approximately $0.07 \mathrm{MPa}$ for the engine speed of 1200-3600 rpm. In case of 2ZR-FXE engine, the characteristics of combustion engine operation in hybrid drive system is significantly different from the operation characteristics of the previous version of the engine. In the current $1.8 \mathrm{dm}^{3}$ version of the engine, within the engine speeds $n=4000-5200 \mathrm{rpm}$, the maximum torque is utilised. This enables taking the full advantage of the characteristics of the combustion engine operation, despite the limited power resulting from the application of the Atkinson cycle. Analogous to the above, the combustion engine with Otto cycle (installed in other Toyota vehicles) develops a torque of $180 \mathrm{~N} \cdot \mathrm{m}$ at a speed of $4000 \mathrm{rpm}$ and the maximum power of $108 \mathrm{~kW}$ at $6400 \mathrm{rpm}$ at the limited compression ratio of up to 10.5 (compared to $\varepsilon=13$ for engine with Atkinson cycle).

The analysis of operating characteristics of combustion engines with higher engine displacement were based on the example of Lexus engine. Two solutions are presented: one fitted with engine with Otto cycle (Lexus GS450h, engine displacement of $3.5 \mathrm{dm}^{3}$ ) and the other with Atkinson cycle (Lexus HS250h, engine displacement of $2.4 \mathrm{dm}^{3}$ ). Very different combustion engine displacements result in different profiles of external characteristics (Fig. 3a). After taking into

a)

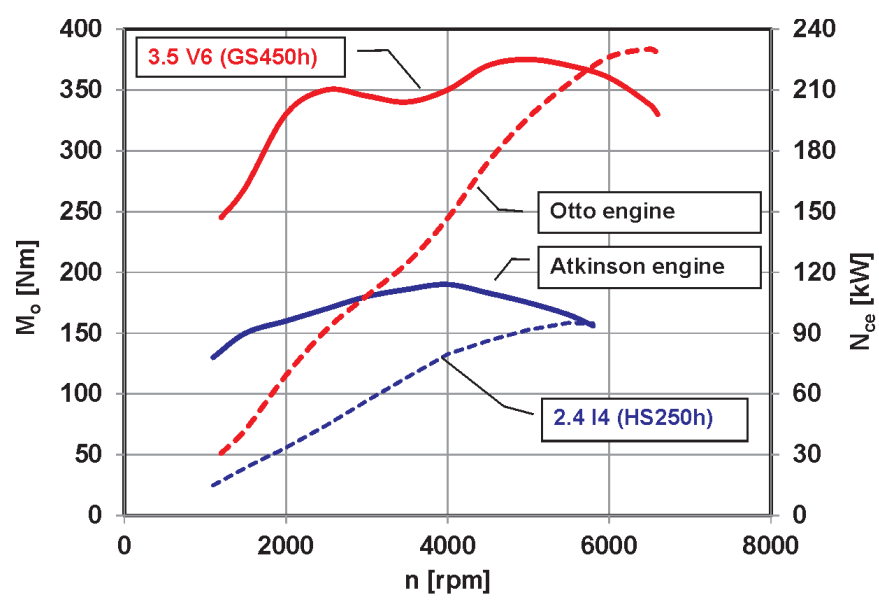

ta wynosi około 0,07 MPa dla prędkości obrotowej silnika wynoszącej 1200-3600 obr/min. W przypadku jednostki 2ZR-FXE charakterystyka pracy silnika spalinowego w napędzie hybrydowym jest znacząco odmienna od charakterystyki pracy silnika w poprzedniej wersji. W obecnej wersji silnika $1,8 \mathrm{dm}^{3} \mathrm{w}$ zakresie prędkości obrotowej $\mathrm{n}=4000-5200$ obr/min wykorzystywany jest maksymalny moment obrotowy. Pozwala to na pełne wykorzystanie charakterystyki pracy silnika spalinowego, mimo ograniczonej mocy wynikającej z zastosowania obiegu Atkinsona. Analogiczny do niego silnik spalinowy z obiegiem Otto (montowany w innych pojazdach Toyoty) rozwija moment obrotowy $180 \mathrm{~N} \cdot \mathrm{m}$ przy prędkości 4000 obr/min oraz moc maksymalną $108 \mathrm{~kW}$ przy $6400 \mathrm{obr} / \mathrm{min}$ przy ograniczonym stopniu sprężania do 10,5 (w stosunku do $\varepsilon=13 \mathrm{z}$ obiegiem Atkinsona).

Analizy charakterystyk pracy silników spalinowych o większych pojemnościach skokowych dokonano na przykładzie silników firmy Lexus. Przedstawiono dwa rozwiązania wyposażone w silnik z obiegiem Otto (Lexus GS450h, silnik o pojemności skokowej $3,5 \mathrm{dm}^{3}$ ) oraz z obiegiem Atkinsona (Lexus HS250h, silnik o pojemności skokowej $2,4 \mathrm{dm}^{3}$ ). Bardzo różne pojemności silników spalinowych skutkują odmiennymi przebiegami charakterystyk zewnętrznych (rys. 3a). Po uwzględnieniu ograniczenia mocy silnika

b)

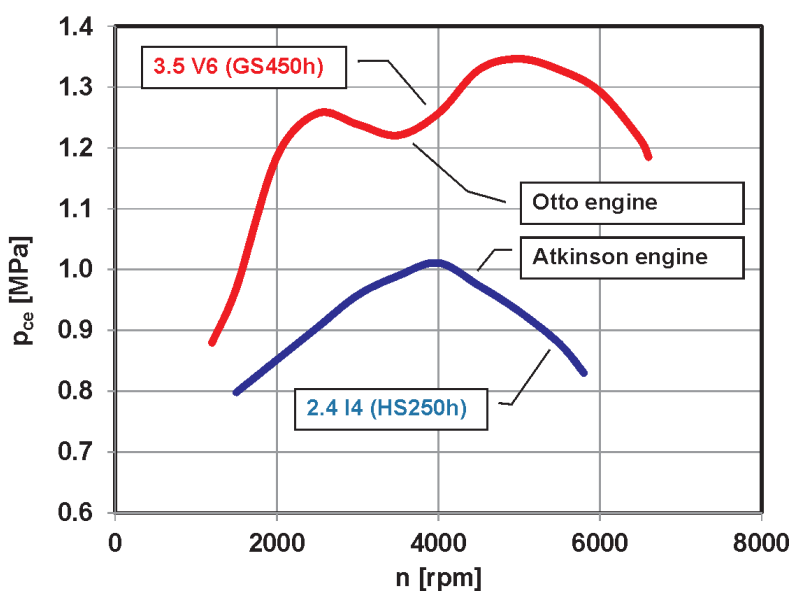

Fig. 3. Characteristics of the combustion engines of hybrid drive systems by Lexus: a) torque and engine power characteristics, b) mean effective pressure characteristics

Rys. 3. Charakterystyka silników spalinowych napędów hybrydowych firmy Lexus: a) przebieg momentu obrotowego i mocy silnika, b) przebieg średniego ciśnienia użytecznego

account the limitations of the power of engine with Atkinson cycle (compression ratio of 12.5), for this combustion engine are achieved lower values of mean effective pressures (Lexus HS250h - Fig. 3b) - by about $22 \%$ in relation to the effective pressure obtained by the GS450h combustion engine. In addition, they occur at different values of the engine speed.

\subsection{The analysis of operation of combustion engines \\ found in the parallel drive systems (mild hybrid)}

The combustion engines used in mild hybrid drive systems to much lesser extent utilize electric motors, due to which the combustion engine power determines signifi- z obiegiem Atkinsona (stopień sprężania wynosi 12,5), uzyskuje się mniejsze wartości średniego ciśnienia użytecznego tego silnika spalinowego (Lexus HS250h - rys. 3b) - o około $22 \%$ w stosunku do ciśnienia użytecznego uzyskanego przez silnik spalinowy GS450h. Dodatkowo występują one przy innych wartościach prędkości obrotowej.

\subsection{Analiza pracy silników spalinowych występujących w napędach równoleglych (mild hybrid)}

Silniki spalinowe wykorzystywane w napędach typu mild hybrid w znacznie mniejszym stopniu wykorzystują silniki elektryczne, co powoduje, że moc silnika spalinowego 
cantly the characteristics of the vehicle drive system. Despite considerable spread of the maximum power of combustion engines (mild hybrid drive systems) - Fig. 1, the powers of electric motors are not significant. The aim of the use of mild hybrid drive is to assist the operation of combustion engine, rather than replace it. This implies that it is purposeful to utilize the electric motor torque in the initial range of engine speeds. It means a significant increase of the torque during starting the vehicle. In case of Porsche Cayenne Hybrid drive there is more than two-fold increase in the value of torque at $\mathrm{n}=1000 \mathrm{rpm}$ (Fig. 4). Compared to the previousgeneration Honda Accord Hybrid drive (the current version is a full hybrid drive as presented in Fig. 1) the increase of the torque in the initial range of the engine speed amounts to $30 \%$. A similar index for Honda CR-Z amounts to $60 \%$. Despite not very high power of electric motors, their properties make it possible to utilize their full power within the range of maximum powers of combustion engines. For the drive systems analysed, the maximum power of the system is the algebraic sum of the maximum power of the combustion engine and maximum power of the electric motor. Similar dependencies do not occur for the full hybrid system. The exception is the Peugeot 3008 HYbrid 4 hybrid drive, as both axles are driven independently by the combustion engine (front axle) and an electric motor (rear axle).

Diverse engine displacements of combustion Honda engines obtain similar values of the mean effective pressure

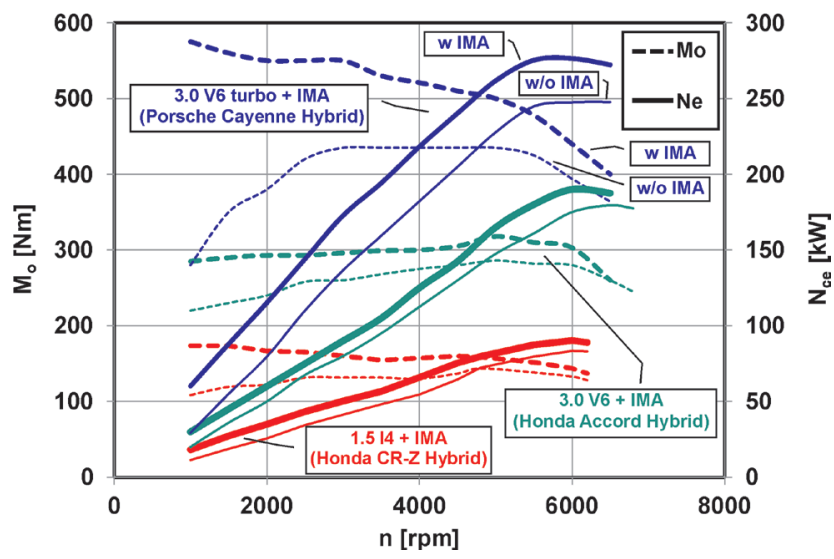

Fig. 4. Characteristics of combustion engines operation and the possibilities of support by electric motors in the selected drives of mild hybrid type vehicles

Rys. 4. Charakterystyki pracy silników spalinowych i możliwości wspomagania przez silniki elektryczne $w$ wybranych napędach pojazdów typu mild hybrid

throughout the whole range of operation of these systems. Within the range of effective speeds $\mathrm{n}=2000-5000 \mathrm{rpm}$, the values of pe are from $1 \mathrm{MPa}$ up to about 1.2 MPa. In the case of a supercharged Porsche 3.0 V6 turbo engine the mean effective pressure values obtain - in the analysed range of engine speeds - from 1.6 to $1.8 \mathrm{MPa}$.

\subsection{Indexes of operation of combustion engines in hybrid drive systems}

The drive systems presented in Fig. 1, show diversified znacząco decyduje o charakterystyce napędowej pojazdu. Mimo dużych rozpiętości mocy maksymalnych silników spalinowych (napędów mild hybrid) - rys. 1, moce silników elektrycznych nie są znaczne. Wykorzystanie napędów typu mild hybrid ma na celu wspomaganie pracy silnika spalinowego, a nie jego zastąpienie. $Z$ tego wynika, że celowe jest wykorzystanie momentu obrotowego silnika elektrycznego w początkowym zakresie prędkości obrotowych silnika spalinowego. Oznacza to znaczny przyrost momentu obrotowego podczas ruszania pojazdem. W przypadku napędu Porsche Cayenne Hybrid jest to ponad dwukrotne zwiększenie wartości momentu obrotowego przy $n=1000$ obr/min (rys. 4). W odniesieniu do poprzedniej generacji napędu Hondy Accord Hybrid (obecna wersja pojazdu ma napęd pełnohybrydowy i przedstawiona została na rys. 1) zwiększenie momentu obrotowego w początkowym zakresie prędkości obrotowych wynosi $30 \%$. Podobny wskaźnik dla Hondy CR-Z wynosi 60\%. Mimo niezbyt dużej mocy silników elektrycznych, ze względu na właściwości tych silników, pozwalają one na wykorzystywanie pełnej ich mocy w zakresie maksymalnych mocy silnika spalinowego. Dla analizowanych jednostek napędowych moc maksymalna układu stanowi sumę algebraiczną maksymalnej mocy silnika spalinowego i maksymalnej mocy silnika elektrycznego. Podobne zależności nie występują dla napędu full hybrid. Wyjątek stanowi napęd hybrydowy Peugeota 3008 HYbrid4, gdyż obie osie napędzane są niezależnie silnikiem spalinowym (oś przednia) i silnikiem elektrycznym (oś tylna).

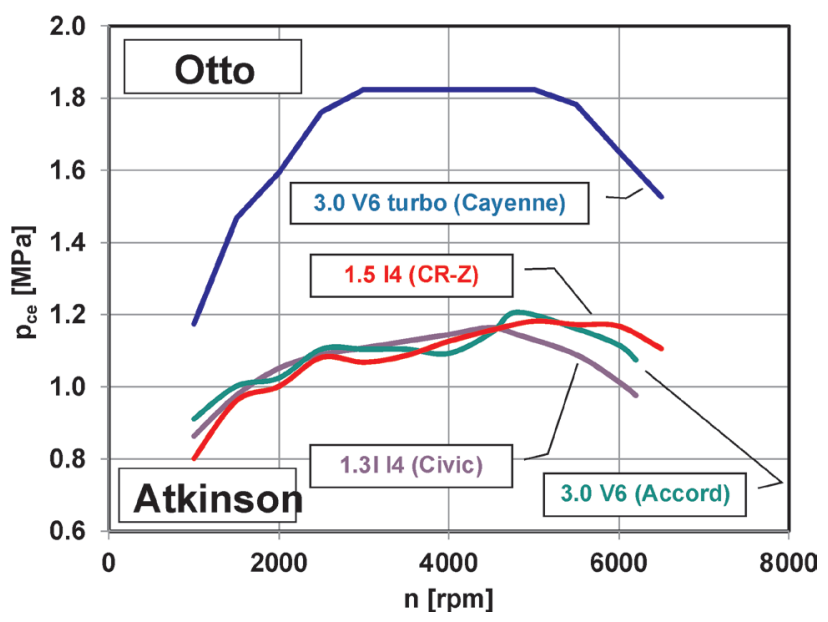

Fig. 5. Mean effective pressure of combustion engines found in the selected mild hybrid drive systems

Rys. 5. Średnie ciśnienie użyteczne silników spalinowych $w$ wybranych napędach typu mild hybrid

Zróżnicowane pojemności skokowe silników spalinowych marki Honda uzyskują zbliżone wartości średniego ciśnienia użytecznego w całym zakresie pracy tych jednostek. W zakresie prędkości użytecznych $\mathrm{n}=2000-5000 \mathrm{obr} / \mathrm{min}$ wartości pe wynoszą od $1 \mathrm{MPa}$ do około 1,2 MPa. W przypadku doładowanego silnika Porsche 3.0 V6 turbo wartość średniego ciśnienia użytecznego wynosi - $\mathrm{w}$ analizowanym zakresie prędkości obrotowych - od 1,6 do 1,8 MPa. 
parameters for combustion engines and electric motors, despite the fact that they are used in the hybrid drive systems. Comparison of parameters of combustion engines, taking into consideration the distinction between types of hybrid drive systems, is shown in Fig. 6. Analysing the figure it might be observed that combustion engines in vehicles of mild hybrid type in majority are not equipped with Atkinson cycle and are characterized by a much higher values of pe than the remaining groups of hybrid drive systems. Depending on the combustion engine used, there might be obtained significant changes in effective pressure. Less significant differences of the mean effective pressure might be observed for full hybrid drive systems, as this index reaches the value of about 1. In the chart shown in Fig. 6, specific powers of the drives $\left(\mathrm{N}_{\mathrm{v}}=\mathrm{N}_{\mathrm{ce}} / \mathrm{V}_{\mathrm{ss}}\right)$ vary significantly, but mostly for full hybrid and mild hybrid drive systems. The operational parameters of combustion engines of hybrid serial drive systems do not differ from engines currently used in other types of vehicles.

The analysis of electric systems of hybrid drive systems indicates the existence of significant differences in the powers of these drive systems. For this reason were introduced indexes of engine drive power enabling comparison of the share of combustion engine utilisation $\left(\mathrm{N}_{\mathrm{ce}}\right)$ in relation to the power of the electric motor $\left(\mathrm{N}_{\mathrm{m}}\right)$ :

$$
\mathrm{N}_{\mathrm{h}}=\mathrm{N}_{\mathrm{ce}} / \mathrm{N}_{\mathrm{m}}[-]
$$

The powers of electric motors in full hybrid drive systems are much more significant than in the mild hybrid drive systems. On the basis of the analysis of Fig. 7 it might be concluded that the mild hybrid drive system now has the power of about $50 \mathrm{~kW}$. Although similar powers of electric motors can occur for all types of hybrid drives (in the

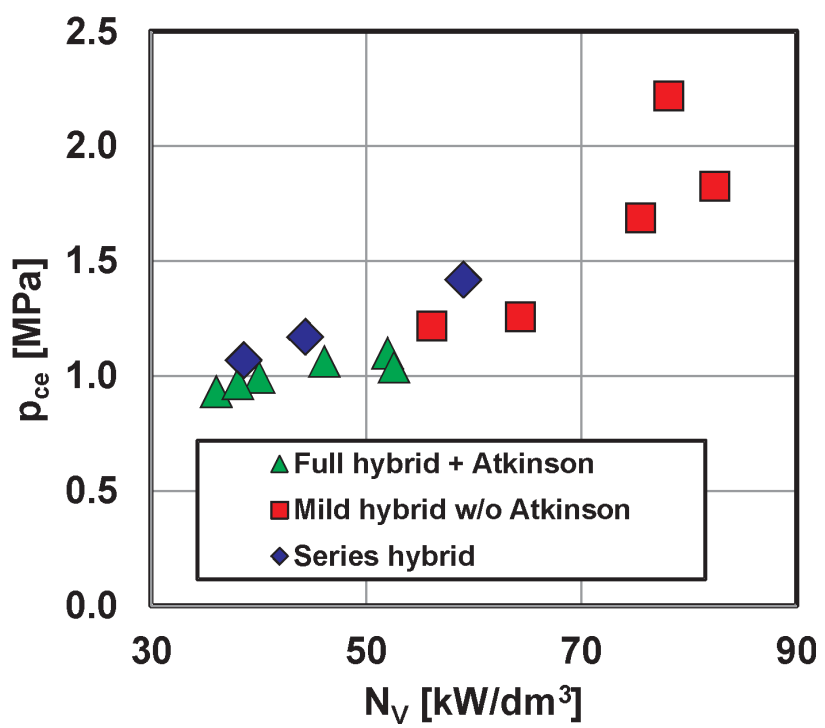

Fig. 6. The maximum mean effective pressure as a function of the unit power of combustion engine including different types of hybrid drive systems

Rys. 6. Maksymalne średnie ciśnienia użyteczne jako funkcja mocy jednostkowej silnika spalinowego w aspekcie zróżnicowanych typów napęów hybrydowych

\subsection{Wskaźniki pracy silników spalinowych napędów} hybrydowych

Układy napędowe zestawione na rys. 1 charakteryzują się zróżnicowanymi parametrami silników spalinowych i elektrycznych, mimo zastosowania ich w napędach hybrydowych. Porównania parametrów silników spalinowych z uwzględnieniem podziału na typy napędów hybrydowych przedstawiono na rys. 6 . Z jego analizy wynika, że silniki spalinowe w pojazdach typu mild hybrid w większości nie są wyposażone w obieg Atkinsona oraz cechują się znacznie większymi wartościami pe niż pozostałe grupy napędów hybrydowych. W zależności od zastosowanego silnika spalinowego uzyskuje się dużą zmianę ciśnienia użytecznego. Mniejsze różnice średniego ciśnienia użytecznego dotyczą napędów typu full hybrid, gdyż wskaźnik ten uzyskuje wartości około 1 . W zestawieniu przedstawionym na rys. 6 moce jednostkowe napędów $\left(\mathrm{N}_{\mathrm{v}}=\mathrm{N}_{\mathrm{ce}} / \mathrm{V}_{\mathrm{ss}}\right)$ znacznie się różnią, jednak najbardziej dla napędów full hybrid i mild hybrid. Silniki spalinowe hybrydowych napędów szeregowych parametrami pracy nie odbiegają od obecnie stosowanych $\mathrm{w}$ innych typach pojazdów.

Analiza układów elektrycznych napędów hybrydowych wskazuje na istnienie znacznych różnic w mocach tych napędów. Z tego względu wprowadzono wskaźnik mocy silników napędowych pozwalający na porównywanie udziału mocy silnika spalinowego $\left(\mathrm{N}_{\mathrm{ce}}\right)$ do mocy silnika elektrycznego $\left(\mathrm{N}_{\mathrm{m}}\right)$ - równanie $(1)$.

Moce silników elektrycznych napędów full hybrid są znacznie większe niż mild hybrid. Na podstawie analizy rysunku 7 można stwierdzić, że napęd mild hybrid ma obecnie moc około $50 \mathrm{~kW}$. Mimo że podobne moce silników elektrycznych mogą występować we wszystkich typach napędów hybrydowych (w zakresie 20-60 kW), to analiza wskaźnika $\mathrm{N}_{\mathrm{h}}$ wskazuje na istnienie znacznych różnic. Napędy szeregowe mają ten wskaźnik znikomy, gdyż główną rolę odgrywa napęd elektryczny. W zakresie $0,9<\mathrm{N}_{\mathrm{h}}<5$ należy spodziewać się napędów typu full hybrid, co oznacza, że napędy

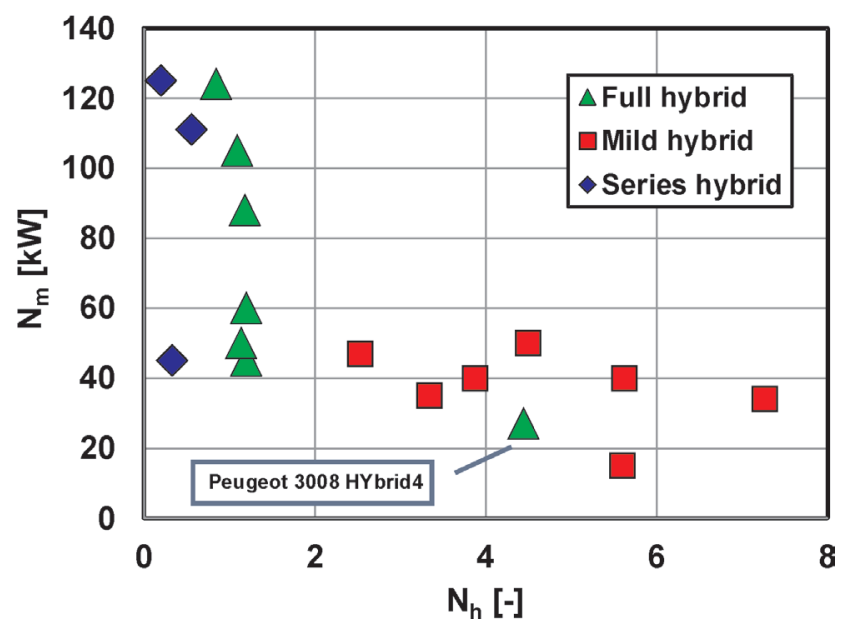

Fig. 7. Index of share of the combustion engine power $N_{h}$ in relation to the power of the electric motor

Rys. 7. Wskaźnik udziału mocy silnika spalinowego do elektrycznego $N_{h}$ w odniesieniu do mocy silnika elektrycznego 
range from 20 to $60 \mathrm{~kW}$ ), the analysis of $\mathrm{N}_{\mathrm{h}}$ index indicates the existence of significant differences. For serial drive systems this index is negligible as the main role is played by electric drive. Within the range of $0.9<\mathrm{N}_{\mathrm{h}}<5$ the full hybrid type drive systems might be expected, which means that these drives can be equipped with electric motors with power comparable to the powers of combustion engines (index close to one). Modern designs of mild hybrid drive systems (e.g. Hyundai, Kia, Peugeot) enable utilisation of an electric motor to obtain a substantial range of the vehicle, through the use of capacious lithium-ion batteries. Compared to the mild hybrid drive systems, the powers of electric motors are lower and, at the same time, their share in relation to the power of the combustion engine is much smaller. Electric motors of such drive systems have powers 4 to 8 times smaller than the combustion engines $\left(\mathrm{N}_{\mathrm{h}}\right.$ index values range from 4 to 8 ).

Taking into account the power of hybrid drive system in relation to $\mathrm{N}_{\mathrm{h}}$ index, there might be observed a change in the position of the power values for specific types of drive systems (Fig. 8). For serial drive systems values of $\mathrm{N}_{h}$ index are the lowest with, simultaneously, the lowest power of the hybrid drive system. Full hybrid drive system has, on average, the power of about $150 \mathrm{~kW}$. In case of mild hybrid drive system, high $\mathrm{N}_{\mathrm{h}}$ index corresponds to substantial values of power of the hybrid drive system.

\section{Hybridization of the drive systems of vehicles}

\subsection{Introduction}

Hybridization is defined as the power of electric drive systems (electric motors) in relation to the sum of all drive systems $[2,6]$ :

$$
H=\frac{\sum_{i} N_{m i}}{\sum_{i}\left(N_{m_{i}}+N_{c e}\right)}
$$

where: $\mathrm{N}_{\mathrm{mi}}$ - is the power of the electric motor in a hybrid vehicle, $\mathrm{N}_{\mathrm{ce}}$ - is the power of the combustion engine.

As a result of the analysis of the hybridization of the drive, e.g. of $3^{\text {rd }}$ generation Toyota Prius $\left(\mathrm{N}_{\mathrm{ce}}=72 \mathrm{~kW}\right.$, $\left.\mathrm{N}_{\mathrm{m}}=60 \mathrm{~kW}\right)$ might be obtained hybridization value $\mathrm{H}=$ $=60 /(60+72) \cdot 100 \%=45 \%$. This means that the hybridization degree of this drive system is $45 \%$. The presented values refer to the value of the drive systems power (combustion engine and electric motor) in the hybrid vehicle. So defined degree of hybridization indicates only the values of power of the installed engines and motors (Fig. 9). It does not indicate the degree of their utilisation or conformity with the characteristics of the vehicle drive systems.

It should be noted that this value (degree of hybridization) enables the classification of hybrid vehicles to the appropriate group, however, it does not define the share of utilisation of combustion engine and electric motor. In the above case, the power of the hybrid drive system is $100 \mathrm{~kW}$. The value calculated in the denominator of the equation (2) for Toyota Prius is $133 \mathrm{~kW}$. It is the result of te mogą być wyposażone w silniki elektryczne o mocach porównywalnych z mocami silników spalinowych (wskaźnik bliski jedności). Nowoczesne konstrukcje napędów mild hybrid (np. Hyundai, Kia, Peugeot) pozwalają na wykorzystanie silnika elektrycznego do uzyskania znacznego zasięgu pojazdu, dzięki wykorzystaniu pojemnych akumulatorów

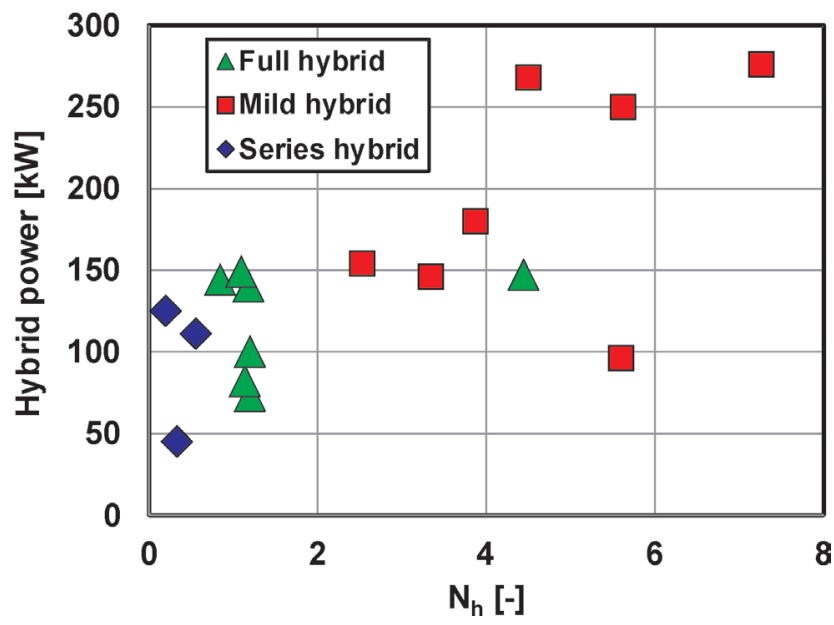

Fig. 8. The power of the hybrid drive in relation to the index of the power of the drive systems $\mathrm{N}_{\mathrm{h}}$

Rys. 8. Moc napędu hybrydowego w odniesieniu do wskaźnika mocy silników napędowych $N_{\text {, }}$

litowo-jonowych. W odniesieniu do napędów mild hybrid moce silników elektrycznych są mniejsze i jednocześnie ich udział w stosunku do mocy silnika spalinowego jest znacznie mniejszy. Silniki elektryczne takich napędów mają moce 4-8-krotnie mniejsze niż silnik spalinowe (wskaźnik $\mathrm{N}_{\mathrm{h}}$ przyjmuje wartości z zakresu 4-8).

Biorąc pod uwagę moc napędu hybrydowego odniesioną do wskaźnika $\mathrm{N}_{\mathrm{h}}$, należy zauważyć zmianę położenia wartości mocy dla określonych typów napędów (rys. 8). Dla napędów szeregowych wartości Nh są najmniejsze, przy jednocześnie najmniejszej mocy napędu hybrydowego. Napęd typu full hybrid ma moc średnio o wartości około $150 \mathrm{~kW}$. W przypadku napędu mild hybrid duży wskaźnik $\mathrm{N}_{\mathrm{h}}$ odpowiada znacznym wartościom mocy napędu hybrydowego.

\section{Hybrydyzacja napędów pojazdów}

\subsection{Wprowadzenie}

Definicję hybrydyzacji przyjmuje się jako moc napędów elektrycznych (silników elektrycznych) odniesioną do sumy mocy wszystkich źródeł napędowych [2, 6] - równanie (2) gdzie: $\mathrm{N}_{\mathrm{mi}}$ - moc i-tego silnika elektrycznego w pojeździe hybrydowym, $\mathrm{N}_{\mathrm{ce}}$ - moc silnika spalinowego.

W wyniku analizy hybrydyzacji napędu np. Toyoty Prius trzeciej generacji $\left(\mathrm{N}_{\mathrm{Ne}}=72 \mathrm{~kW}, \mathrm{~N}_{\mathrm{m}}=60 \mathrm{~kW}\right)$ można otrzymać $\mathrm{H}=60 /(60+72) \cdot 100 \%=45 \%$. Oznacza to, że stopień hybrydyzacji tego napędu wynosi $45 \%$. Przedstawione wartości odnoszą się do wartości mocy silników (spalinowego i elektrycznego) pojazdu hybrydowego. Tak określony stopień hybrydyzacji wskazuje jedynie na wartości mocy zainstalowanych silników (rys. 9). Nie wskazuje on jedno- 


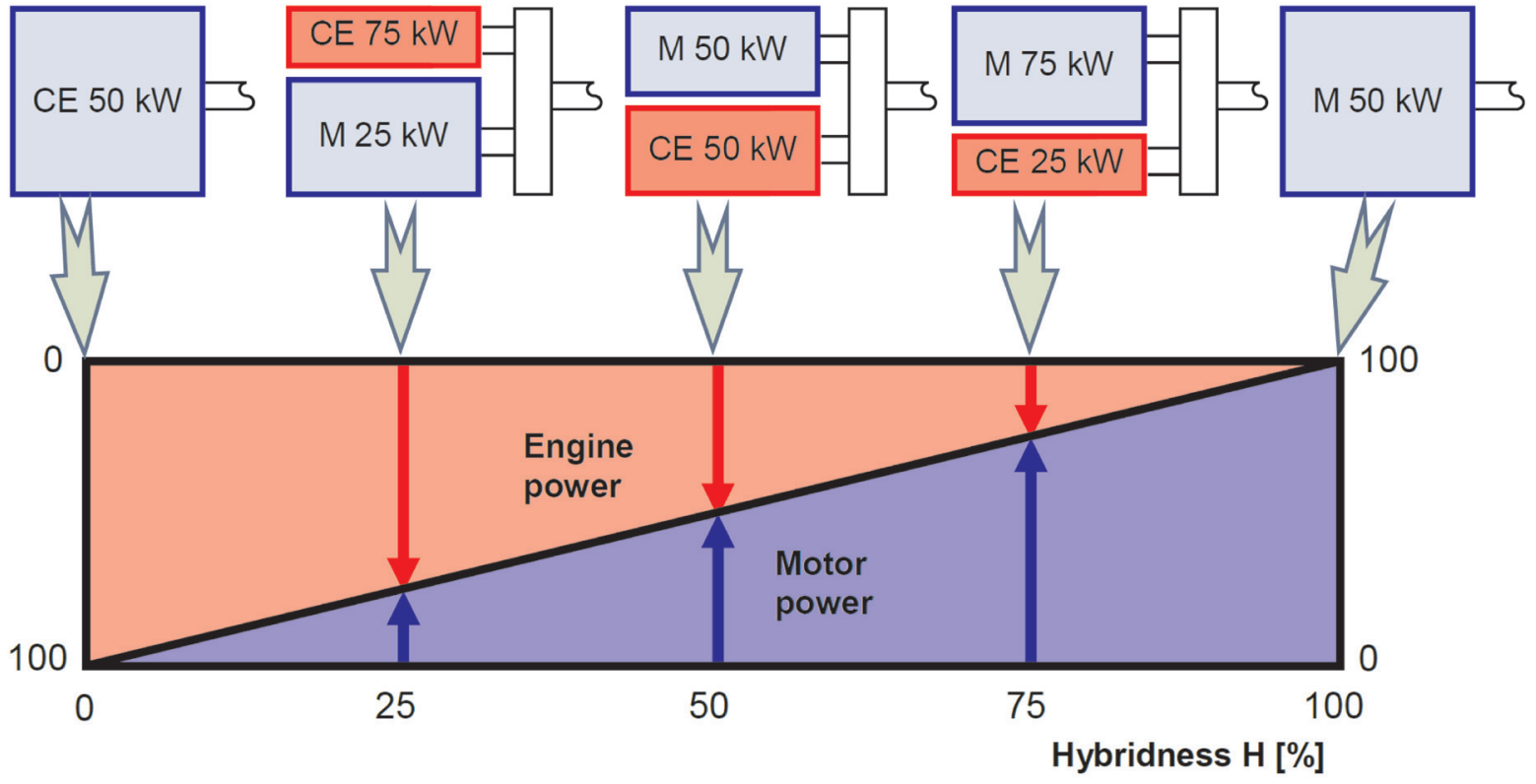

\section{$\mathrm{M}$ - electric motor, $\mathrm{CE}$ - combustion engine}

Fig. 9. Changes in the degree of hybridization for various hybrid drive systems $[9,11]$ Rys. 9. Zmiany stopnia hybrydyzacji dla różnych układów napędów hybrydowych [9, 11]

an algebraic sum of the power of both drive systems. The obtained difference results from the fact that the ranges of maximum power of combustion engine and electric motor are achieved at different speeds. For this reason, there has been introduced the actual drive hybridization index $\mathrm{H}_{\mathrm{R} 1}$. It is defined as:

$$
\mathrm{H}_{\mathrm{R} 1}=\frac{\sum_{\mathrm{i}} \mathrm{N}_{\mathrm{mi}}}{\mathrm{N}_{\mathrm{w}}}
$$

where: $\mathrm{N}_{\mathrm{mi}}$ - is the power of the electric motor in a hybrid vehicle, $\mathrm{N}_{\mathrm{w}}$ - is the maximum power on the vehicle wheels transferred by the hybrid drive system.

So formulated definition enables determination of the actual extent of utilisation of electric drive systems in hybrid vehicles. Most of the modern designs of hybrid drive systems do not allow to obtain the maximum power of electric motor and combustion engine in given driving conditions. This means that the denominator of the equation (3) is actually lower, leading to the dependency $\mathrm{H}<\mathrm{H}_{\mathrm{R}}$. The abovementioned discrepancies led to determination of the actual extent of hybridization of drive systems. The theoretical index of hybridization was taken into consideration as well as the actual one determined on the basis of formula (3).

\subsection{Index of hybridization of the vehicles drive systems}

The analyses of hybrid drive systems were held for vehicles currently produced and available on the market. The vehicles were selected from among types of hybrid drives presented in Fig. 1. Significant discrepancies of the presented types of hybrid drive systems indicate the lack of a uniform structure of that market. Hybridization indexes for drive systems from each of the groups are shown in Fig. 10. cześnie na stopień ich wykorzystania lub dopasowania do charakterystyki napędowej pojazdu.

Należy zwrócić uwagę, że wartość ta (stopień hybrydyzacji) pozwala na zaszeregowanie pojazdów hybrydowych do odpowiedniej grupy, jednak nie określa udziału wykorzystania silników napędowych (elektrycznych i spalinowego). W powyższym przypadku moc napędu hybrydowego wynosi 100 kW. Obliczona w mianowniku równania (2) wartość dla Toyoty Prius to $133 \mathrm{~kW}$. Jest ona wynikiem algebraicznej sumy mocy obu napędów. Uzyskana różnica wynika z tego, że zakresy maksymalnych mocy obu silników otrzymuje się przy innych prędkościach obrotowych. $Z$ tego powodu wprowadzono rzeczywisty wskaźnik hybrydyzacji napędów $\mathrm{H}_{\mathrm{R} 1}$ - równanie (3),

gdzie: $\mathrm{N}_{\mathrm{mi}}$ - moc i-tego silnika elektrycznego w pojeździe hybrydowym, $\mathrm{N}_{\mathrm{w}}$ - maksymalna moc na kołach pojazdu przenoszona przez układ hybrydowy.

Tak sformułowana definicja umożliwia określenie rzeczywistego stopnia wykorzystania napędów elektrycznych w pojazdach hybrydowych. Większość współczesnych konstrukcji napędów hybrydowych nie pozwala na uzyskiwanie maksymalnych mocy silników elektrycznych i spalinowego podczas danych warunków jazdy. Oznacza to, że mianownik równania (3) jest w rzeczywistości mniejszy, co prowadzi do zależności $\mathrm{H}<\mathrm{H}_{\mathrm{R}}$. Powyżej przedstawione rozbieżności skłoniły do określenia rzeczywistego stopnia hybrydyzacji napędów. Uwzględniono przy tym zarówno teoretyczny wskaźnik hybrydyzacji, jak i rzeczywisty określony na podstawie wzoru (3).

\subsection{Wskaźniki hybrydyzacji napędów pojazdów}

Analizę napędów hybrydowych prowadzono dla obecnie produkowanych i dostępnych na rynku pojazdów. Wyboru 


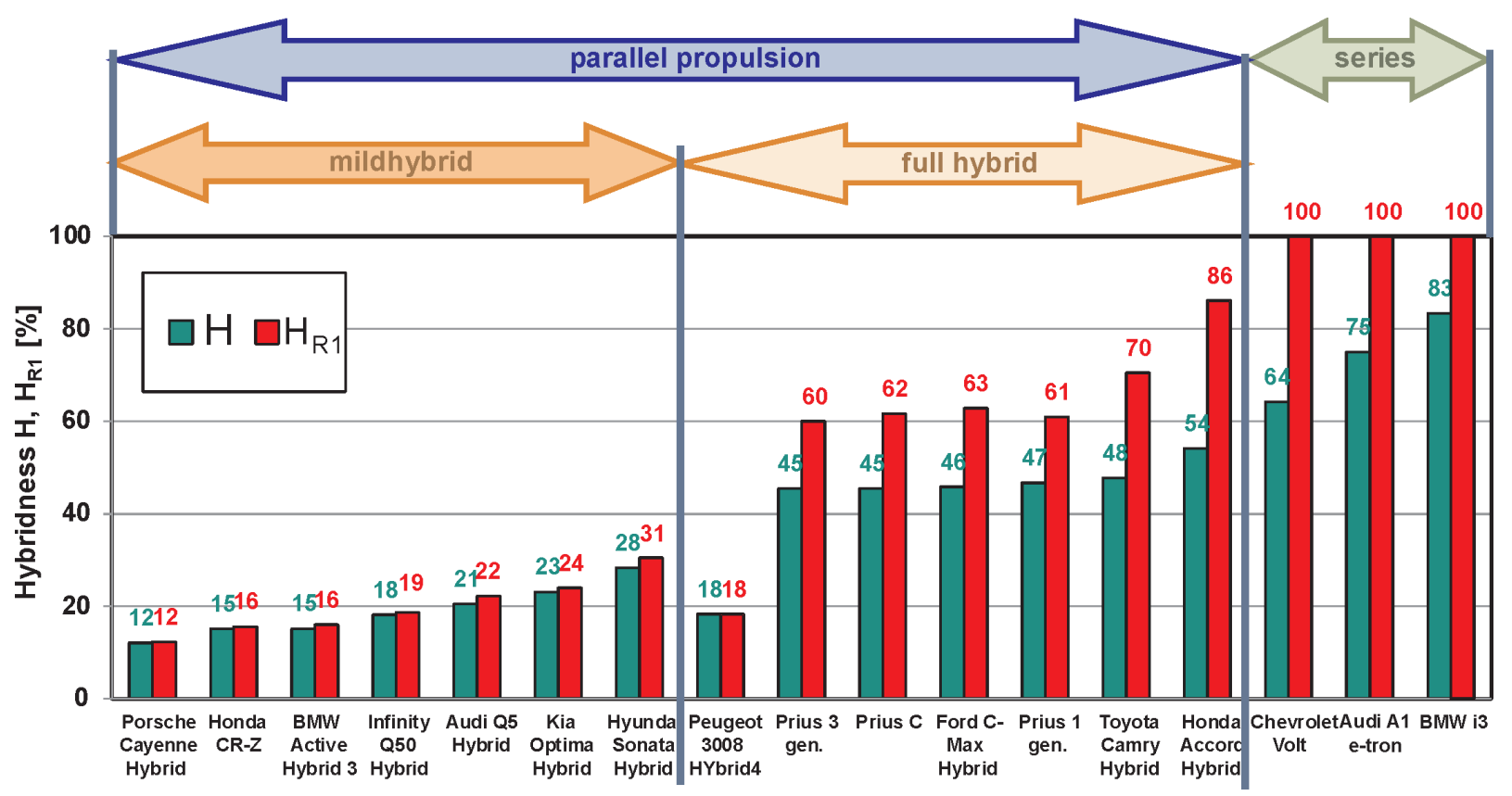

Fig. 10. The summary of hybridization indexes for the presented solutions of the drive systems Rys. 10. Zestawienie wskaźników hybrydyzacji prezentowanych rozwiazań układów napędowych

The analysis of hybridization indexes indicates that their larger values are obtained when the formula (3) is used than in case of the formula (2). This is due to the reduced power of the entire drive system in relation to the algebraic sum of powers of engine and motor. However, in case of the Peugeot 3008 hybrid drive system the indexes take the same values. Obtaining the same values of $H$ and $H_{R}$ results from the fact that in the drive system was introduced separation for the axes of the vehicle. The low hybridization index results from significant disproportion of drive powers of combustion engines and electric motors (4.4 times higher power of combustion engine than of electric motor).

Hybridization index for serial drive systems is always $100 \%$, regardless of the size of the utilised combustion engine. For this reason, a revised equation (3) should be found, in order to take fully into account the variable extent of hybridization $\mathrm{H}_{\mathrm{R} 2}$ also in serial drive systems. Thus it was suggested to take into consideration the so-called deterioration factor including the influence of the value of the engine and motor powers in relation to the power transferred to the wheels:

$$
H_{R 2}=\frac{\sum_{i} N_{m i}}{\sum_{i}\left(N_{m_{i}}+N_{c e}\right) A}
$$

where: $\mathrm{N}_{\mathrm{mi}}$ - is the power of the electric motor in a hybrid vehicle, $\mathrm{N}_{\mathrm{w}}$ - is the maximum power on the vehicle wheels transferred by the hybrid drive system, $\mathrm{A}-$ is the deterioration factor $\sum_{\mathrm{i}}\left(\mathrm{N}_{\mathrm{mi}}+\mathrm{N}_{\mathrm{ce}}\right) / \mathrm{N}_{\mathrm{w}}$.

The A factor amounts to 1 when the hybrid drive system has independent combustion engine and electric motor driv- pojazdów dokonano spośród rodzajów napędów hybrydowych przedstawionych na rysunku 1. Znaczne rozbieżności mocy zaprezentowanych typów napędów hybrydowych wskazują na brak jednolitej struktury tego rynku. Wskaźniki hybrydyzacji napędów każdej z grup przedstawiono na rys. 10.

Analiza wskaźników hybrydyzacji wskazuje, że ich większe wartości otrzymuje się przy wyznaczaniu za pomocą wzoru (3) niż wzoru (2). Wynika to z obniżonej mocy całego układu napędowego w stosunku do algebraicznej sumy mocy silników. Jednak w przypadku napędu hybrydowego Peugeota 3008 wskaźniki przyjmują jednakowe wartości. Uzyskanie jednakowych wartości $\mathrm{H}$ oraz $\mathrm{H}_{\mathrm{R}}$ wynika z tego, że w układzie napędowym zastosowano rozdzielenie napędu na osie pojazdu. Mały wskaźnik hybrydyzacji jest rezultatem dużych dysproporcji w mocach silników napędowych $(4,4$ razy większa moc silnika spalinowego niż elektrycznego).

Wskaźnik hybrydyzacji układów szeregowych wynosi zawsze $100 \%$, niezależnie od wielkości zastosowanego silnika spalinowego. Z tego powodu należy poszukiwać zmienionego równania (3), pozwalającego na pełne uwzględnienie zmiennego stopnia hybrydyzacji $\mathrm{H}_{\mathrm{R} 2}$ również $\mathrm{w}$ napędach szeregowych. Z tego względu zaproponowano uwzględnienie tzw. współczynnika pogorszenia ujmującego wpływ wielkości mocy silników pojazdu do mocy przenoszonej na koła - równanie (4),

gdzie: $\mathrm{N}_{\mathrm{mi}}$ - moc i-tego silnika elektrycznego w pojeździe hybrydowym, $\mathrm{N}_{\mathrm{w}}$ - maksymalna moc na kołach pojazdu przenoszona przez układ hybrydowy, A - współczynnik pogorszenia zdefiniowany jako $\sum_{\mathrm{i}}\left(\mathrm{N}_{\mathrm{mi}}+\mathrm{N}_{\mathrm{ce}}\right) / \mathrm{N}_{\mathrm{w}}$.

Współczynnik A przyjmuje wartość 1, gdy napęd hybrydowy ma niezależne silniki spalinowy i elektryczny napędzające osobne osie napędowe. Wtedy wskaźnik teoretyczny 


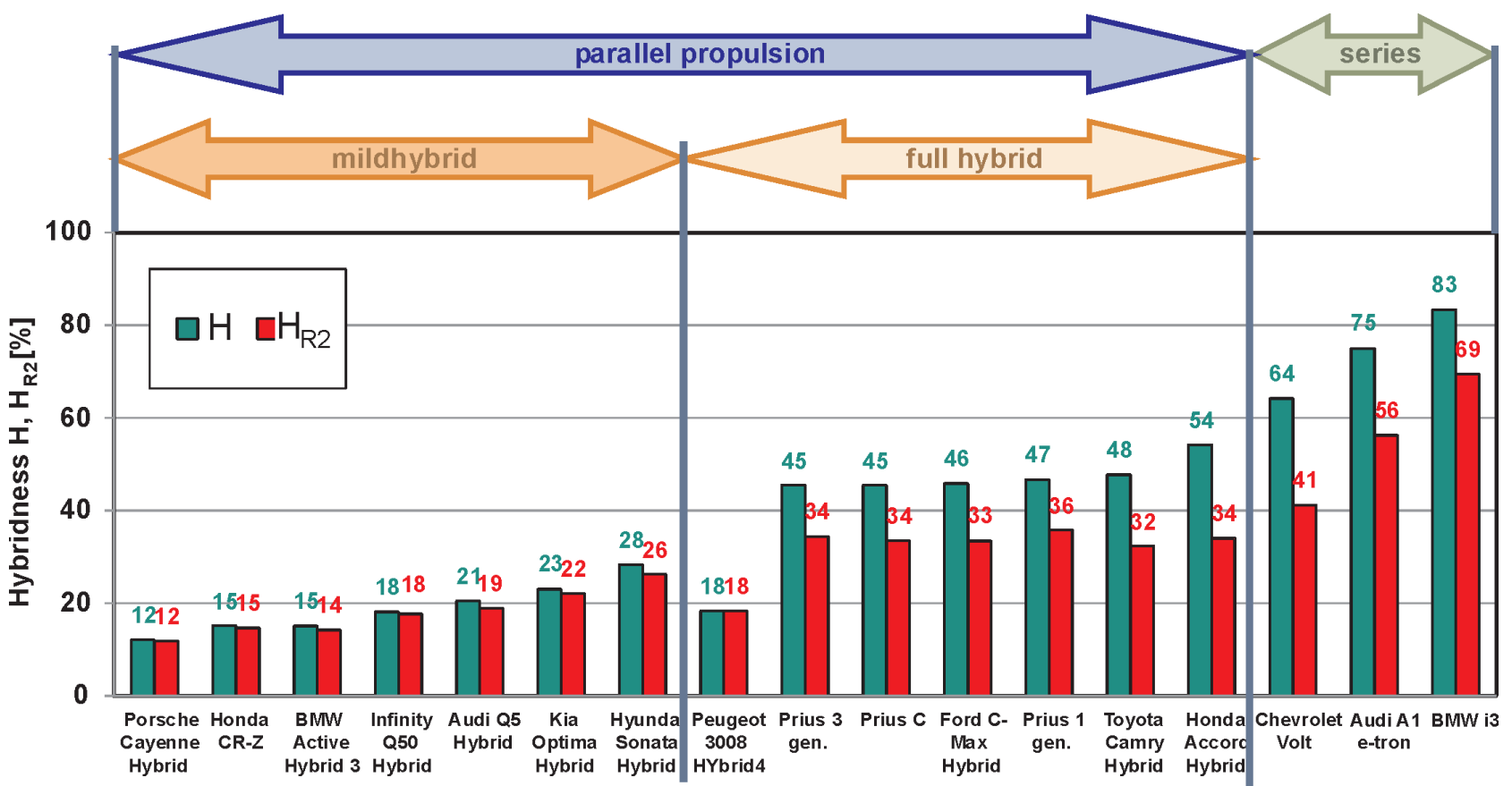

Fig. 11. The summary of hybridization indexes for the presented solutions of the drive systems including the deterioration factor Rys. 11. Zestawienie wskaźników hybrydyzacji rozwiazań układów napędowych uwzględniających współczynnik pogorszenia

ing separate axles. Then the theoretical index $\mathrm{H}$ is equal to $\mathrm{H}_{\mathrm{R} 2}$. In other cases, index $\mathrm{A}$ is greater than 1. This means that the value $\mathrm{H}_{\mathrm{R} 2}$ should be equal to or less than $\mathrm{H}$. Taking into account such an amendment allows for obtaining different hybridization indexes also for the vehicles with serial hybrid drive system. The results of the calculations taking into account $\mathrm{H}_{\mathrm{R} 2}$ index are shown in Fig. 11 .

The comparison of the hybridization degree with the share of the combustion engine power in relation to electric
$\mathrm{H}$ jest równy $\mathrm{H}_{\mathrm{R} 2}$. W pozostałych przypadkach wskaźnik A jest większy od 1. Oznacza to, że wartość $H_{R 2}$ powinna być równa $\mathrm{H}$ lub mniejsza od $\mathrm{H}$. Uwzględnienie takiej poprawki pozwala na uzyskanie zróżnicowanych wskaźników hybrydyzacji również dla pojazdów o hybrydowym napędzie szeregowym. Wyniki obliczeń uwzględniające wskaźnik $\mathrm{H}_{\mathrm{R} 2}$ przedstawiono na rys. 11.

Zestawienie stopnia hybrydyzacji z udziałem mocy silnika spalinowego do elektrycznego daje obraz hybrydy-

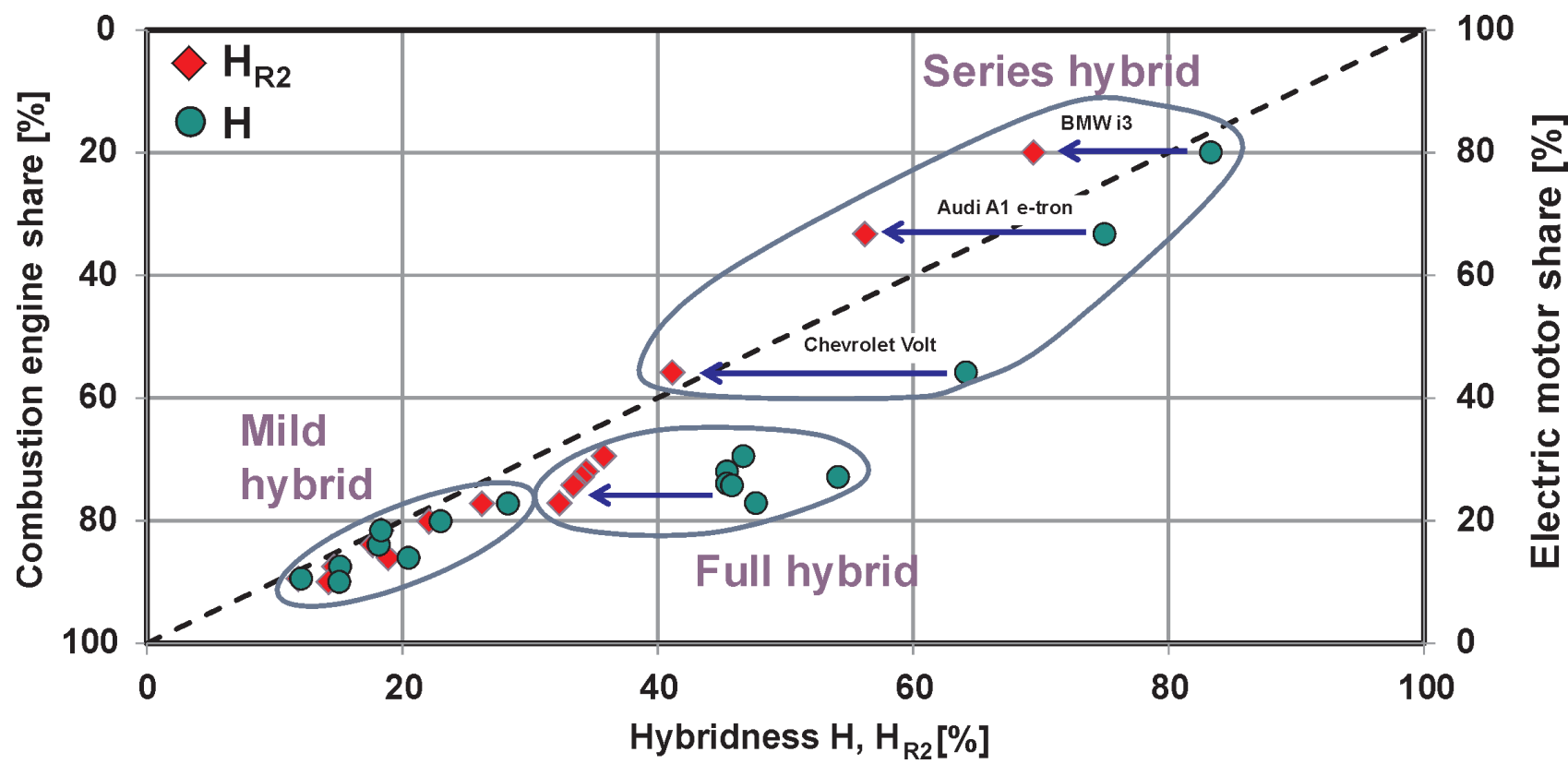

Fig. 12. Hybridization indexes $\left(\mathrm{H}_{\mathrm{R} 2}\right.$ - the actual index taking into account the deterioration factor, $\mathrm{H}$ - theoretical index $)$ against the share of the combustion engine and electric motor power of the analysed hybrid drive systems

Rys. 12. Wskaźniki hybrydyzacji ( $H_{R 2}$ - rzeczywisty uwzględniający współczynnik pogorszenia, H - teoretyczny) na tle udziału mocy silnika spalinowego i elektrycznego analizowanych układów hybrydowych 
motor power exemplifies the hybridization of drive systems (Fig. 12). From the analysis of the figure ensues (as predicted), that with the development of hybrid drive systems (mild hybrid - full hybrid - serial drive) the share of electric drive systems increases. This causes an increase in the degree of hybridization of drive systems. The compilation implies that the indexes of hybridization of drive systems take the following values:

- for mild hybrid drive systems: $10 \%-30 \%$,

- for full hybrid drive systems: $30 \%-40 \%$,

- for serial drive systems: $40 \%-70 \%$.

Analysing the theoretical and actual degree of hybridization, a reduction of the actual index of hybridization might be observed (after inclusion of the deterioration factor). The most significant differences of these indicators are obtained when analysing serial drive systems (the least significant are observed for drives of mild hybrid type), as the combustion engine does not transfer the power to the drive wheels of the vehicle.

\section{Conclusions}

The presented solutions of hybrid drive systems are the latest designs of the currently produced vehicles. The hybrid drive systems: serial, parallel and mixed were analysed. The presented indexes of hybridization define the degree of hybridization determined in two ways. The theoretical index $\mathrm{H}$ depends primarily on the difference between the electric motor power and combustion engine power. The higher the power of the electric motor and the lower the power of the combustion engine, the higher the degree of hybridization $\mathrm{H}$. Therefore, the highest value for this index is obtained in vehicles, in which the primary drive is the electric motor. In this situation, the highest values are observed for vehicles of Range Extender type, in which the combustion engine is used only to recharge the batteries. The actual index of hybridization $\mathrm{H}_{\mathrm{R} 2}$ reflects the ratio of the power of an electric motor (or motors) against the power that can be transferred to the wheels of the vehicle, taking into account the disproportion between the power on wheels and the power on drives (the electric motors or one electric motor and one combustion engine) in the vehicle. This is an index that to a larger extent reflects the nature of the hybrid drive system, as it takes into account the real possibilities of utilisation of both sources of propulsion in the vehicle. The index determined on the basis of the equation (3) is less than the theoretical index, however, it should be noted that only for the electric vehicle this indicator obtains a value of 1 (or $100 \%$ ).

The indexes of hybridization of drive systems obtained in the analysis take the following values:

- for mild hybrid drive systems: $10 \%-30 \%$,

- for full hybrid drive systems: $30 \%-40 \%$,

- for serial drive systems: $40 \%-70 \%$.

The subsequent phase of research on the degree of hybridization of hybrid drive systems should be the possibility of creating a numerical classification of hybrid systems including the types of drive systems (electric motor and combustion engine) and the battery capacity, since the range of the hybrid vehicle depends on these components. zacji napędów (rys. 12). Z jego analizy wynika (zgodnie z przewidywaniami), że wraz z rozwojem napędów hybrydowych (mild hybrid - full hybrid - napęd szeregowy) udział napędów elektrycznych zwiększa się. Powoduje to zwiększenie stopnia hybrydyzacji napędów. $\mathrm{Z}$ zestawienia wynika, że wskaźniki hybrydyzacji napędów przyjmują następujące wartości:

- dla napędów mild hybrid: $10 \%-30 \%$,

- dla napędów full hybrid: $30 \%-40 \%$,

- dla napędów szeregowych: $40 \%-70 \%$.

Analizując teoretyczny i rzeczywisty stopień hybrydyzacji, można zauważyć zmniejszenie wartości rzeczywistego wskaźnika hybrydyzacji (następuje uwzględnienie wskaźnika pogorszenia). Największe różnice tych wskaźników uzyskuje się podczas analizy napędów szeregowych (najmniejsze dla napędów typu mild hybrid), gdyż silnik spalinowy nie przekazuje mocy do kół napędowych pojazdu.

\section{Wnioski}

Przedstawione rozwiązania napędów hybrydowych są najnowszymi konstrukcjami obecnie produkowanych pojazdów. Analizie poddano hybrydowe układy szeregowe, równoległe oraz mieszane. Przedstawione wskaźniki hybrydyzacji określają stopień hybrydyzacji wyznaczony dwoma sposobami. Teoretyczny wskaźnik H zależy przede wszystkim od różnicy mocy między silnikami elektrycznym i spalinowym. Im większa moc silnika elektrycznego oraz im mniejsza moc silnika spalinowego, tym większy stopień hybrydyzacji $\mathrm{H}$. Z tego względu największą wartość tego wskaźnika uzyskują pojazdy, w których podstawowym źródłem napędu jest silnik elektryczny. W tej sytuacji najwyższe wartości mają pojazdy typu Range Extender, w których niewielkiego silnika spalinowego używa się tylko w celu doładowania akumulatorów. Rzeczywisty wskaźnik hybrydyzacji $\mathrm{H}_{\mathrm{R} 2}$ przedstawia stosunek mocy silnika elektrycznego (lub silników) do mocy jaką można otrzymać na kołach pojazdu przy uwzględnieniu dysproporcji między mocą na kołach a mocą silników (elektrycznych lub jednego elektrycznego i spalinowego) w pojeździe. Jest to wskaźnik, który w większym stopniu oddaje naturę napędu hybrydowego. Uwzględnia on bowiem rzeczywiste możliwości wykorzystania obu źródeł napędowych pojazdu. Wskaźnik wyznaczony za pomocą równania (3) przyjmuje wartości mniejsze niż wskaźnik teoretyczny, jednak należy zauważyć, że tylko dla pojazdu elektrycznego wskaźnik ten uzyskuje wartość równą 1 (lub 100\%).

Otrzymane w wyniku analiz wskaźniki hybrydyzacji napędów przyjmują następujące wartości:

- dla napędów mild hybrid: $10 \%-30 \%$,

- dla napędów full hybrid: $30 \%-40 \%$,

- dla napędów szeregowych: $40 \%-70 \%$.

Dalszym etapem prac dotyczących stopnia hybrydyzacji napędów hybrydowych powinna być możliwość stworzenia klasyfikacji liczbowej napędów hybrydowych, uwzględniająca typ silników (elektrycznego i spalinowego) oraz pojemność akumulatorów, gdyż od tych składników zależy zasięg pojazdu hybrydowego. 


\section{Abbreviation/Skróty i oznaczenia}

A deterioration factor/współczynnik pogorszenia

$\mathrm{CO}_{2}$ carbon dioxide/dwutlenek węgla

$\mathrm{H}$ hybridization/hybrydyzacja

$\mathrm{H}_{\mathrm{R} 1} \quad$ actual drive hybridization index/rzeczywisty wskaźnik hybrydyzacji

$\mathrm{H}_{\mathrm{R} 2}$ actual drive hybridization index included deterioration factor/rzeczywisty wskaźniki hybrydyzacji uwzględniajacy wspótczynnik pogorszenia

Mo torque/moment obrotowy

This article was financially supported within the project "Engineer of the Future. Improving the didactic potential of the Poznan University of Technology" - POKL.04.03.00-00-259/12, implemented within the Human Capital Operational Programme, co-financed by the European Union within the European Social Fund.
$\mathrm{N}_{\mathrm{ce}} \quad$ engine power/moc silnika spalinowego

$\mathrm{N}_{\mathrm{h}}^{\mathrm{ce}} \quad$ index of vehicle power/wskaźnik mocy silników napędowych

$\mathrm{N}_{\mathrm{m}} \quad$ power of the electric motor/moc silnika elektrycznego

$\mathrm{N}_{\text {mi }}$ power of the electric motor in a hybrid vehicle/moc i-tego silnika elektrycznego w pojeździe hybrydowym

$\mathrm{N}_{\mathrm{V}} \quad$ specific powers/moc właściwa

$\mathrm{p}_{\mathrm{ce}} \quad$ mean effective pressure/średnie ciśnienie użyteczne

Publikacja powstała $w$ ramach realizacji projektu "Inżynier Przyszłości. Wzmocnienie potencjału dydaktycznego Politechniki Poznańskiej.", nr POKL.04.03.00-00-259/12, wspólfinansowanego ze środków Unii Europejskiej w ramach Europejskiego Funduszu Społecznego.

\section{Bibliography/Literatura}

[1] automobiles.honda.com/accord-plug-in/specifications.aspx

[2] Borowski P., Pielecha I., Cieślik W., Bueschke W., Czajka J., Hybrydyzacja układów napędowych pojazdów samochodowych. Logistyka 3/2013, 665-670, ISSN 1231-5478.

[3] Cieślik W., Borowski P., Pielecha I., Bueschke W., Czajka J., Wisłocki K., Systemy recyrkulacji spalin we współczesnych konstrukcjach silnikowych. Logistyka 3/2013, 1118-1127, ISSN 1231-5478.

[4] carmarket.com.pl (dostęp z dnia 15.08.2014).

[5] Borowski P., Pielecha I., Cieślik W., Bueschke W., Czajka J., Statyczny i dynamiczny downsizing silników spalinowych. Logistyka 3/2013, 671-679, ISSN 1231-5478.

[6] Fuhs A.E., Hybrid vehicles and the future of personal transportation. CRC Press 2008

[7] Higuchi N., Sunaga Y., Tanaka M., Shimada H., Development of a New Two-Motor Plug-In Hybrid System, SAE Int. J. Alt. Power. 2(1):135-145, 2013, doi:10.4271/2013-01-1476.

[8] Langen P., Future Mobility Solutions of the BMW Group. 33. Internationales Wiener Motorensymposium 2012.

[9] Merkisz J., Pielecha I., Alternatywne napędy pojazdów. Wydawnictwo Politechniki Poznańskiej, Poznań 2006.

[10] Merkisz J., Pielecha I., Borowski P.: Parametry eksploatacyjne silników spalinowych w pojazdach typu Range Extender. Autobusy 4/2013, s. 26-30.

[11] mnordan.com/2013/02/28/the-very-curious-hybrid-boom (dostęp z dnia 15.08.2014).

Wojciech Cieślik, MEng. - postgraduate at the Faculty of Machines and Transportation of Poznan University of Technology.

Mgr inż. Wojciech Cieślik - doktorant na Wydziale Maszyn Roboczych i Transportu Politechniki Poznańskiej.

e-mail:wojciech.m.cieslik@doctorate.put.poznan.p

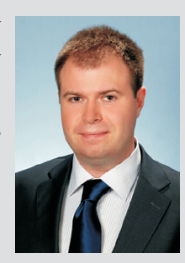

Jakub Czajka, DEng. - doctor at the Faculty of Machines and Transport of Poznan University of Technology.

Dr inż. Jakub Czajka - adiunkt na Wydziale Maszyn Roboczych i Transportu Politechniki Poznańskiej. e-mail: jakub.czajka@put.poznan.pl
[12] motoren.wordpress.com (dostęp z dnia 15.08.2014).

[13] samar.com.pl (dostęp z dnia 15.08.2014).

[14] Uehara, T., Takahashi, Y., Oki, R., Hirasawa, T. et al., Development of the New THS-II Powertrain for Compact Vehicles, SAE Technical Paper 2012-01-1017, 2012, doi:10.4271/201201-1017.

[15] www.audi.co.uk/about-audi/latest-news/audi-a1-e-tron-zeroemissions-in-the-city.html (dostęp z dnia 15.08.2014).

[16] www.bmw.pl/pl/pl/newvehicles/i/i3/2013/showroom/drive. html (dostęp z dnia 15.08.2014).

[17] www.hybridcars.com/bmw-i3-electric-car-overview (dostęp z dnia 15.08.2014).

[18] www.hyundaiusa.com (dostęp z dnia 15.08.2014).

[19] Yonekawa A., Ueno M., Watanabe O., Ishikawa N., Development of New Gasoline Engine for ACCORD Plug-in Hybrid, SAE Technical Paper 2013-01-1738, 2013, doi:10.4271/201301-1738.

Ireneusz Pielecha, DSc., DEng. - doctor at the Faculty of Machines and Transport of Poznan University of Technology.

Dr hab. inż. Ireneusz Pielecha - adiunkt na Wydziale Maszyn Roboczych i Transportu Politechniki Poznańskiej.

e-mail: ireneusz.pielecha@put.poznan.pl

Przemysław Borowski, MEng. - postgraduate at the Faculty of Machines and Transport of Poznan University of Technology.

Mgr inz. Przemysław Borowski - doktorant na Wydziale Maszyn Roboczych i Transportu Politechniki Poznańskiej.

e-mail: przemyslaw.t.borowski@doctorate.put.poznan.pl
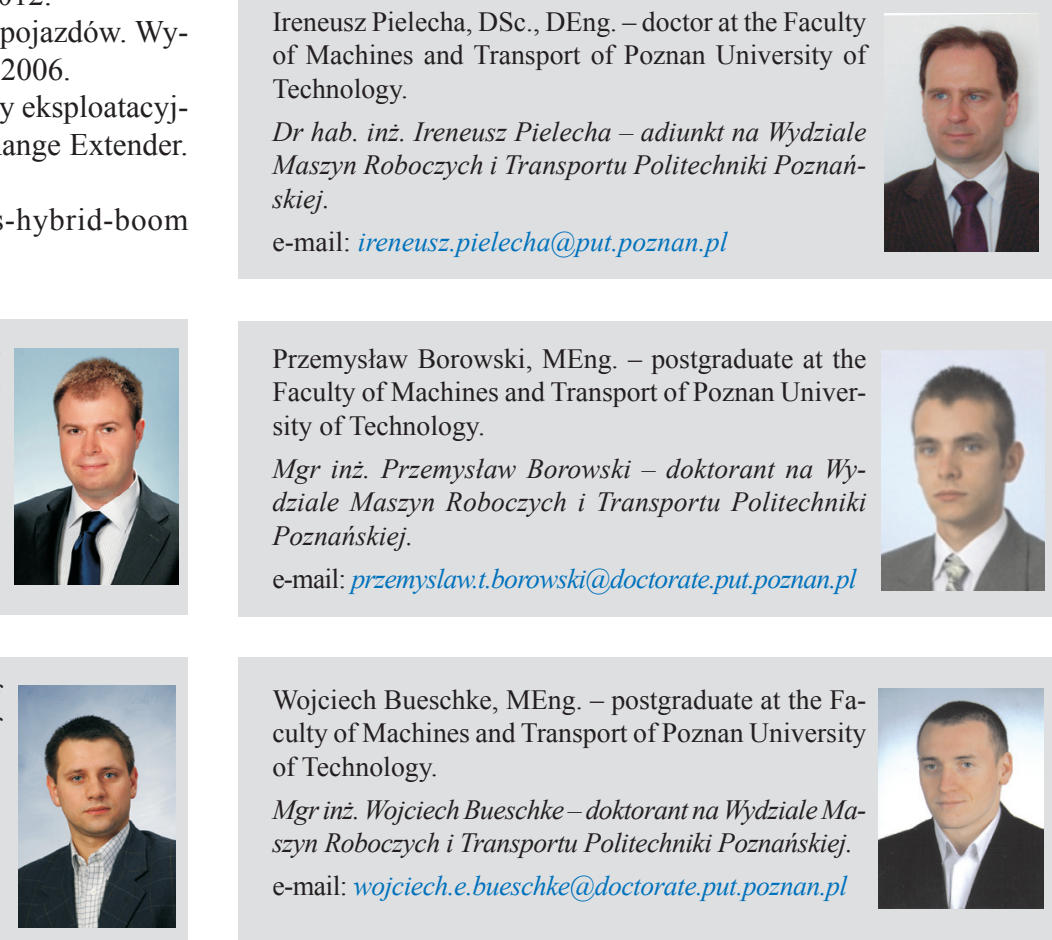

Wojciech Bueschke, MEng. - postgraduate at the Faculty of Machines and Transport of Poznan University of Technology.

Mgrinz. Wojciech Bueschke-doktorant na Wydziale Maszyn Roboczych i Transportu Politechniki Poznańskiej. e-mail:wojciech.e.bueschke@doctorate.put.poznan.pl 